\title{
Studies in New Testament Ethics
}

WILLIAM LILLIE

In view of the current revival of Biblical Theology the author looks at what the New Testament as a whole teaches both on more theoretical questions like the doctrine of Natural Law, the authority of conscience or the contribution of knowledge to the good life and on more practical questions like the use of wealth, the place of work or the nature of marriage and divorce. In conclusion Dr Lillie, who is lecturer in Biblical Study at Aberdeen University, attempts an analysis of the two central ethical concepts of the New Testament-self-denial and love.

Price 18s. net

\section{Calvin's Commentaries}

\section{A New Translation}

Edited by D. W. TORRANCE and T. F. TORRANCE

The publication of the first volumes in this new and accurate translation of John Calvin's great commentaries on the New Testament has been widely welcomed. The translation will be issued in twelve volumes during the next few years.

$\begin{array}{lll}\text { St John 1-10 Translated by T. H. L. PARKER } & \text { 25s. net }\end{array}$

$\begin{array}{lll}\text { St John 11-21 Translated by T. H. L. PARKER } & \text { 25s. net }\end{array}$

1 Corinthians Translated by J. W. FRASER 27s. 6 d. net

Romans and Thessalonians

Translated by ROSS MACKENZIE 30s. net

\section{OLIVER \& BOYD}

Tweeddale Court, 14 High Street, Edinburgh 1 


\section{The Scrolls and Christian Origins}

The Rev. Professor M. BLACK DD FBA Have the Scrolls any light to shed on the origins of Christianity? This is the main problem which is investigated in this book. It is divided into two parts, historical and theological. The first examines the question of the origins and identity of the Qumran sect: the sect of the scrolls is the same as the ancient Jewish sect of the Essenes, and crystallized out of the older movement of the Hasidaeans of Maccabaean times. The second part discusses the religious institutions and theological conceptions of the scrolls, in particular those which seem to possess some relationship or resemblance to any Christian ideas or institutions.

$2 \mathrm{IS}$

\section{The Revised Standard Version of the Holy Bible}

Over 10,000,000 copies of the RSV have now been sold in the Englishspeaking world-by far the most popular version of the Complete Bible. Of the numerous editions of the RSV available from Lectern Editions at fi 2. Ios. to $f 34$, the newest presentation is the $4 \frac{3}{4} " \times 2 \frac{3}{4}^{\prime \prime}$ Pocket New Testament, India Paper: Rexine 15s; Full Leather 305; Full Leather, Yapp Edge $35 s$ (all in black, blue or maroon bindings).

\section{An Introduction to Christian Doctrine}

T. E. JESSOP ' $H$ is book is quite first-rate and one is reminded of the work of the late Dr A. E. Taylor...Professor Jessop has noticed... the eager and even wistful interest in religious matters which, even since the war, has been evinced by many who are outside the Church.' Church Times I $2 s 6 d$

\section{HERDER-NELSON \\ New Testament Introduction}

A. WIKENHAUSER 'The treatment... is clear, informed and sensible. Well-deserved praise has already been given to the chapter on formcriticism and should be given to the chapter on textual criticism. It will be useful to students.... The long bibliographies giving details of Roman Catholic continental scholarship, will be specially useful to specialists.... This work will impress non-Catholics as remarkably open-minded.' Church of England Newspaper

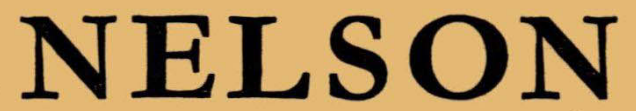

